\title{
TINGKAT SUKU BUNGA PEMBIAYAAN USAHA MIKRO DAN UKM TERHADAP TINGKAT PERTUMBUHAN PEREKONOMIAN INDONESIA
}

\author{
Gunawan ${ }^{1)}$ \\ Mugi Rahardjo ${ }^{2)}$ \\ Evi Gravitiani ${ }^{3)}$ \\ Fakultas Ekonomi Dan Bisnis Universitas Sebelas Maret \\ goenaone2303@gmail.com
}

\begin{abstract}
ABSTRAK
Pertumbuhan ekonomi merupakan perkembangan kegiatan dalam perekonomian yang menyebabkan barang dan jasa yang diproduksi dalam masyarakat bertambah dan mengakibatkan terjadinya peningkatan kemakmuran masyarakat. Tingkat bunga menentukan investasi yang akan memberi keuntungan kepada para pengusaha. Semakin rendah tingkat bunga semakin banyak investasi yang dilakukan para pengusaha. Jenis penelitian ini adalah penelitian kausalitas yaitu penelitian yang ingin mencari penjelasan dalam bentuk hubungan sebab akibat (cause-effect) antar beberapa konsep atau beberapa variable independent yakni meliputi Suku Bunga Pembiayaan Usaha Mikro Dan UKM dan Produktivitas Usaha dan Tenaga Kerja, serta variable dependent yaitu Pertumbuhan Ekonomi. Dalam penelitian ini analisis data menggunakan pendekatan Regresi Data Panel menggunakan Software Eviews. Tujuan penggunaan sofware Evies adalah membantu peneliti untuk tujuan prediksi. Hasil penelitian menunjukkan bahwa Suku Bunga Pembiayaan Usaha Mikro Dan UKM berpengaruh signifikan terhadap terhadap Tingkat Pertumbuhan Ekonomi dengan nilai t-statistic sebesar 0,027612 $(<0,05)$ sedangkan Produktivitas Usaha dan Tenaga Kerja juga berpengaruh signifikan terhadap Tingkat Pertumbuhan Ekonomi dengan nilai t-statistic sebesar 0,011741 $(<0,05)$.
\end{abstract}

Kata kunci : Suku Bunga, Produktivitas Usaha, Pertumbuhan Ekonomi

\section{LATAR BELAKANG}

Kondisi perekonomian merupakan dimensi penting dalam penyelenggaraan kebijakan negara untuk dapat dicapai secara optimal. Kondisi perekonomian sering menjadi indikator kualitas sebuah negara. Pertumbuhan ekonomi dapat menjadi indikator kondisi perekonomian. Pertumbuhan ekonomi mencerminkan kegiatan ekonomi. Bab ini membahas konsep pertumbuhan ekonomi dengan berbagai cakupannya, yang kemudian diakhiri dengan pertanyaan latihan.

Pertumbuhan ekonomi merupakan perkembangan kegiatan dalam perekonomian yang menyebabkan barang dan jasa yang diproduksi dalam masyarakat bertambah dan mengakibatkan terjadinya peningkatan kemakmuran masyarakat. Perjalanan dari waktu ke waktu, diharapkan kemampuan suatu negara untuk menghasilkan barang dan jasa semakin meningkat. Pertumbuhan ekonomi yang tinggi merupakan dambaan semua negara. Lalu, apa sebenarnya yang dimaksud dengan pertumbuhan ekonomi. Beberapa ahli memberikan pengertian tentang pertumbuhan ekonomi.
Pertumbuhan ekonomi suatu negara sebagai kemampuan negara itu untuk menyediakan barang-barang ekonomi yang terus meningkat bagi penduduknya berdasarkan pada kemajuan teknologi dan kelembagaan serta penyesuaian ideologi yang dibutuhkannya. Definisi Kuznets menekankan bagaimana kapasitas suatu negara dalam memaksimalkan mesin produksinya untuk mencapai output yang maksimal.

Pertumbuhan ekonomi sebagai proses kenaikan output per kapita dalam jangka panjang. Definisi ini menekankan tiga aspek yang perlu diperhatikan, yaitu: 1). Proses, 2). Output per kapita, 3). Jangka panjang. Pertumbuhan ekonomi adalah suatu proses, bukan suatu gambaran ekonomi pada suatu saat. Pertumbuhan ekonomi harus memberikan kontribusi pada pendapatan per kapita, dan pertumbuhan ekonomi menyangkut jangka waktu yang panjang. Pertumbuhan ekonomi yang mapan tidak bisa diukur dalam waktu yang pendek.

Pertumbuhan dan pembangunan ekonomi memiliki definisi yang berbeda, yaitu pertumbuhan ekonomi ialah proses kenaikan output per kapita yang terus menerus dalam 
jangka panjang. Pertumbuhan ekonomi tersebut merupakan salah satu indikator keberhasilan pembangunan. Dengan demikian, makin tingginya pertumbuhan ekonomi biasanya makin tinggi pula kesejahteraan masyarakat, meskipun terdapat indikator yang lain yaitu distribusi pendapatan.

Berdasarkan pada pandangan di atas, maka dapat ditarik kesimpulan bahwa pertumbuhan ekonomi merupakan proses perubahan kondisi perekonomian suatu negara secara berkesinambungan menuju keadaan yang lebih baik dari waktu sebelumnya. Pertumbuhan ekonomi dapat diartikan juga sebagai proses kenaikan kapasitas produksi suatu perekonomian yang diwujudkan dalam bentuk kenaikan pendapatan nasional. Adanya pertumbuhan ekonomi merupakan indikasi keberhasilan pembangunan ekonomi.

Sejak sebelum kemerdekaan ekonomi Indonesia telah dilihat sebagai suatu perekonomian yang dualistik sebagaimana diungkapkan oleh Boeke. Penjajahan Belanda yang panjang telah mengukuhkan keadaan tersebut dengan dualisme pendekatan pembangunan yang memperkenalkan kegiatan onderneming yang dipisahkan dari perekonomian rakyat sehingga enclave economy hadir, dari perkebunan kemudian meluas sampai pada perusahaan perminyakan dan mastchapai lainnya. Setelah kemerdekaan kita mengenal kegiatan perekonomian rakyat, usaha milik Negara dan usaha swasta dengan keinginan kuat mengembangkan koperasi sebagai bangun perusahaan yang sesuai untuk menjadi wadah perekonomian rakyat.

Ketika isu modernisasi mengedepan dan keterbukaan mulai merasuk ke dalam perekonomian kita, maka perkembangan internasional yang relevan mulai berkembang dalam perjalanan perekonomian kita. Pada awal Repelita III isu usaha formal dan informal mulai berkembang disertai nuansa pembelaan pada produksi dalam negeri dan pengusaha golongan ekonomi lemah. Pada periode berikutnya sejak 199-0an tuntutan untuk melepaskan dari karakteristik lemah muncul, sehingga lahir pemikiran tentang usaha kecil.

Pemihakan kepada usaha kecil berkembang dan menjadi salah satu perhatian pemerintah hingga datangnya krisis yang meneguhkan lagi kekuatan usaha kecil dan menengah. Indonesia telah menikmati masa pertumbuhan ekononomi yang tinggi dalam jangka waktu yang panjang, hingga datangnya krisis nilai tukar tereskalasi menjadi krisis multi dimensi yang dimulai akhir tahun 1997. Setelah lima tahun lebih krisis tersebut berlangsung dan hingga akhir 2002 tingkat output agregatpun belum kembali pada tingkat sebelum krisis.

\section{Tingkat dan Struktur Suku Bunga}

Setelah kita memahami secara teoritis tentang suku bunga seperti pada uraian di atas, maka suku bunga dalam prakteknya terdapat beberapa hal yang melingkupinya, diantaranya faktor yang menentukan tingkat bunga. Dalam tata kelola sistem keuangan, struktur tingkat bunga ditentukan oleh oleh; jangka waktu dari klaim keuangan, karakteristik perpajakan dari klaim keuangan, derajat risiko tunggakan dari klaim keuangan, dan kemudahan pemasaran dari klaim keuangan dan faktor-faktor lainnya.

Perbedaan jangka waktu dari klaim keuangan biasanya merupakan faktor yang paling banyak dipertimbangkan. Hubungan antara jangka waktu dan suku bunga disebut struktur masa dari suku bunga. Sedangkan ketiga determinan lainnya juga merupakan faktor penting, namun seringkali lebih mudah dalam menentukan pengaruhnya terhadap struktur suku bunga.

Cara yang paling sering digunakan untuk melukiskan hubungan antara suku bunga dan jangka waktu dari klaim keuangan adalah kurva hasil. Akan tetapi faktor-faktor apa saja yang mempengaruhi bentuk kurva hasil sampai saat ini belum ditemukan suatu kesimpulan yang pasti, yang tentunya didukung dengan data empiris. Terkait dengan hal tersebut dikembangkan tiga teori, yaitu; teori harapan, teori premium likuiditas, dan teori pasar tersegmen.

Teori harapan menyatakan bahwa suku bunga jangka panjang sama dengan suku bunga jangka pendek yang berjalan ditambah suku bunga jangka pendek yang diharapkan pelaku pasar yang berlangsung hingga jatu temponya sekuritas jangka panjang. Misal suku bunga untuk obligasi sepuluh tahun harus sama dengan penjumlahan suku bunga jangka pendek yang berjalan dengan suku bunga jangka pendek yang diantisipasi akan terjadi sepanjang obligasi jangka panjang dibagi jangka waktu dari obligasi jangka panjang.

Teori premium likuiditas berlandaskan pada teori harapan, akan tetapi menolak asumsi bahwa peserta pasar berlaku sama 
dalam hal obligasi jangka pendek dan jangka panjang. Menurut teori ini tingkat bunga jangka panjang sama dengan rata-rata dari tingkat bunga jangka pendek yang berjalan, tingkat bunga jangka pendek yang diharapkan dan premium likuditas.

Teori pasar tersegmentasi beranggapan bahwa tingkat bunga jangka pendek dan tingkat bunga jangka panjang ditentukan didalam pasar yang relatif terpisah. Pasar-pasar ini dipisahkan karena alasan kelembagaan. Misal, banyak pembeli sekuritas dalam pikirannya mempunyai kebutuhan tertentu yang biasanya berkaitan dengan sifat dari utang, sehingga membatasi pembeliannya pada segmen dari spektrum jatuh waktu.

Struktur tingkat bunga pada umumnya berdasarkan jangka waktu. Dalam dunia perbankan, tingkat untuk deposito berjangka biasanya dibedakan dalam kisaran 1 bulan, 3 bulan, 6 bulan, dan 12 bulan, baik untuk mata uang lokal maupun valuta asing.

\section{Peran Suku Bunga dalam Perekonomian.}

Tingkat bunga menentukan investasi yang akan memberi keuntungan kepada para pengusaha. Keputusan investasi ditentukan oleh seberapa besar perbandingan tingkat pengembalian modal dan tingkat bunga. Jika tingkat pengembalian modal lebih tinggi dari tingkat bunga, maka pengusaha akan menentukan keputusan investasi, demikian sebaliknya. Apabila tingkat bunga menjadi lebih rendah, lebih banyak usaha yang mempunyai tingkat pengembalian modal yang lebih tinggi daripada tingkat suku bunga. Semakin rendah tingkat bunga yang harus dibayar para pengusaha, semakin banyak usaha yang dapat dilakukan para pengusaha. Semakin rendah tingkat bunga semakin banyak investasi yang dilakukan para pengusaha.

Tingkat bunga mempunyai beberapa fungsi atau peranan penting dalam perekonomian, yaitu;

1. Membantu mengalirnya tabungan berjalan kearah investasi guna mendukung pertumbuhan perekonomian.

2. Mendistribusikan jumlah kredit yang tersedia, pada umumnya memberikan dana kredit kepada proyek investasi yang menjanjikan hasil tertinggi.

3. Menyeimbangkan jumlah uang beredar dengan permintaan akan uang dari suatu negara.
4. Merupakan alat penting menyangkut kebijakan pemerintah melalui pengaruhnya terhadap jumlah tabungan dan investasi.

Suku bunga mempunyai peran signifikan dalam perekonomian. Suku bunga dapat menjadi referensi keputusan yang akan diambil oleh pelaku ekonomi, utamanya pengusaha yang akan menanamkan modalnya. Dengan demikian pergerakan tingkat suku bunga dapat menjadi indikator baik buruknya kondisi perekonomian, yang dapat dilihat dari sektor investasi. Tingkat suku bunga yang relatif stabil menjadikan investasi lebih stabil pula. Sebaliknya kondisi tingkat bunga yang sulit dikontrol menjadikan investasi tidak menentu yang bisa berdampak pada kondisi perekonomian menjadi sulit untuk dikendalikan.

\section{Kendala UKM untuk Menjadi Mesin Pertumbuhan Perekonomian Nasional}

Memperhatikan analisis pada bagian sebelumnya dapat kita catat bahwa kita belum berhasil mengidentifikasi potensi usaha kecil sebagai motor pertumbuhan ekonomi bagi pemulihan krisis ekonomi. Untuk dapat mencerna secara tepat faktorfaktor yang menjadi kendala bagi ekspansi usaha kecil maka diperlukan pendalaman dengan membuat disagregrasi kelompok usaha kecil. Sebagaimana diketahui sesuai hasil pengolahan data tahun 2017 dari sektor usaha kecil sekitar 97\% terdiri dari usaha kecil-kecil (mikro) dengan omset dibawah Rp. 50 juta,-. Dengan demikian mayoritas usaha kecil adalah usaha mikro dan sebagian terbesar berada di sektor pertanian dan perdagangan, hotel dan restoran.

Masalah mendasar yang membatasi ekspansi usaha kecil adalah realitas bahwa produktivitasnya rendah sebagaimana diperlihatkan oleh nilai tambah/tenaga kerja. Secara keseluruhan perbandingan nilai tambah/tenaga kerja untuk usaha kecil hanya sekitar seperduaratus (1/200) kali nilai tambah/tenaga kerja untuk usaha besar. Jika dilihat periode sebelum krisis dan keadaan pada saat ini ketika mulai ada upaya ke arah pemulihan ekonomi. Pada tahun 2017, mengecil menjadi 0,55 . Hal ini menunjukkan bahwa potensi untuk menutup gap antara produktivitas UK dan UB malah menjadi semakin tipis, atau jurang perbedaan produktivitas (nilai tambah/tenaga kerja) akan 
tetap besar. Sudah menjadi pengertian umum bahwa produktivitas sektor industri, terutama industri pengolahan seharusnya mempunyai nilai tambah yang lebih besar. Sebenarnya sektor pertanian memiliki produktivitas terendah dalam pembentukan nilai tambah terutama di kelompok usaha kecil yang hanya merupakan sekitar tiga perempat produktivitas usaha kecil secara keseluruhan yang didominasi oleh usaha pertanian. Namun pengalaman Indonesia di masa krisis menunjukan, bahwa yang terjadi sebaliknya dengan demikian dalam suasana krisis masih sangat sulit mengharapkan sektor industri kecil kita untuk diharapkan menjadi motor pertumbuhan untuk pemulihan ekonomi.

Pembentukan nilai tambah / tenaga

kerja untuk kelompok usaha yang sama (usaha kecil) di berbagai sektor dapat menggambarkan potensi peningkatan produktivitas melalui transformasi dari sektor tradisional ke sektor modern misalnya dari sektor pertanian ke sektor industri dan perdagangan. Rasio nilai tambah/TK untuk UK-pertanian dibanding UK-Industri pengolahan mengalami peningkatan dari 0,74 pada tahun 2016 menjadi 0,82 pada tahun 2017. Peningkatan ini menggambarkan bahwa industri pengolahan semasa krisis tidak memberikan kontribusi nyata dalam perbaikan produktivitas dibanding usaha kecil di sektor pertanian. Alasan lain yang dapat menjelaskan fenomena tersebut adalah kenyataan bahwa di sektor industri selama krisis sebagian besar berproduksi dibawah kapasitas penuh atau bahkan menganggur sehingga nilai tambah/TK tidak memunjukkan peningkatan yang berarti.

Pertanyaan kritis yang harus dijawab adalah apakah sub-sektor industri kecil mampu di gerakkan dalam jangka pendek, karena terbukti selama tiga tahun melewati krisis kecenderungannya sama yakni sekedar bertahan dari keterpurukan lebih parah. Untuk melihat potensi relatif sektor industri sebagai instrumen transformasi sektor tradisional (pertanian) ke modern (industri pengolahan) atau proses kegiatan lanjutan untuk nilai tambah, maka dapat dilihat kemajuan relatif produktivitas kedua sektor untuk usaha kecil. Rasio nilai tambah/tenaga kerja pada tahun 2016 sebesar 0,55 berubah menjadi 0,56 pada tahun 2017 ini berarti tidak terjadi kemajuan yang berarti dalam perbaikan produktivitas, atau krisis justru menyebabkan "back push" atau dorongan ke belakang ke sektor tradisional.

Hambatan untuk meningkatkan produktivitas usaha kecil mikro tidak terlepas dari kemampuan mengadopsi teknologi termasuk untuk alih usaha, alih kegiatan dan alih komoditas. Karena selama ini meskipun mereka telah mengalami transformasi dari sektor pertanian ke non pertanian namun tetap dalam papan bawah. Apabila keadaan ini tidak dapat didobrak maka yang terjadi adalah apapun program yang dicurahkan bagi pengembangan usaha mikro tidak berhasil meningkatkan nilai tambah. Atau jika berhasil nilai tambah tersebut diserap oleh sektor lain yang menyediakan input atau jasa pendukung bagi usaha mikro. Gambaran ini mengindikasikan bahwa industri kecil tidak dapat memikul harapan yang terlampau besar untuk menjadi motor pertumbuhan.

\section{Produktivitas Usaha dan Tenaga Kerja}

Salah satu ukuran kualitas kelompok usaha dalam sumbangannya terhadap produksi nasional adalah produktivitas yang dapat diukur dengan ukuran output per unit usaha. Krisis bukan hanya menyebabkan surutnya jumlah perusahaan, namun juga membawa akibat langsung berupa penurunan output perusahaan. Kondisi menurunnya produktivitas perusahaan secara menyeluruh ini masih terjadi hingga tahun 2012, baru kemudian tumbuh kembali. Demikian juga dengan produktivitas usaha kecil yang terlihat semakin tidak menentu karena kembali terjadi penurunan. Sektor-sektor yang mengalami kemerosotan kembali produktivitas perusahaan pertanian, pertambangan dan galian, listrik dan gas, bangunan dan jasa-jasa. Sementara sektor jasa keuangan yang semula terus menurun mulai menunjukkan tanda-tanda perkembangan yang positif. Salah satu jawaban terhadap perkembangan yang tidak menggembirakan ini adalah karena unit usaha baru yang tumbuh umumnya berskala mikro dan berada di sektor dengan produktivitas rendah.

Adalah menarik jika diperhatikan sektor yang memiliki produktivitas tertinggi untuk perusahaan skala kecil adalah sektor keuangan, persewaan dan jasa perusahaan yang nilainya delapanpuluh kali produktivitas usaha kecil sektor pertanian atau empatpuluh kali rata-rata produktivitas usaha kecil secara keseluruhan. Gambaran ini menggambarkan 
dua hal : (i). sektor pertanian kurang berorientasi nilai tambah tetapi lebih menekankan produktivitas fisik sehingga menjadi ekstrim rendah; dan (ii). sektor jasa keuangan, persewaan dan jasa perusahaan merupakan sektor yang paling produktif dan paling memberikan sumbangan positif bagi pengembangan UKM terutama usaha kecil mikro.

Secara empiris cukup banyak bukti yang menunjukkan pentingnya jasa keuangan dan jasa perusahaan yang efisien sebagai faktor penting bagi dukungan pengembangan usaha lebih lanjut. Gambaran produktivitas usaha pada perusahaan skala menengah sungguh sangat berbeda di mana sektor pertanian memiliki produktivitas usaha yang paling produktif, bahkan hampir empat kali rata-rata produktivitas perusahaan skala menengah secara keseluruhan. pada kelompok ini yang kurang produktif adalah sektor jasajasa yang memang umumnya belum mapan benar. Agak berbeda dengan kelompok usaha kecil pada kelompok usaha menengah ini peningkatan produktivitas terasa amat berat kecuali sektor pertanian yang masih tumbuh positif secara konsisten selama empat tahun terakhir. Jika kita amati kinerja produktivitas usaha pada kedua kelompok ini mengisyaratkan perlunya restrukturisasi perusahaan pertanian menuju skala menengah. Hal ini sejalan dengan pemikiran tentang perlunya peningkatan kepadatan investasi pertanian untuk mengejar keuntungan usaha pertanian yang sesuai dengan biaya oportunitas dari tanah pertanian yang harganya semakin meningkat.

Pada perusahaan skala menengah sektor jasa keuangan tidak menempati tempat teratas, namun masih menempati tempat ketiga setelah sektor angkutan dengan yang masih jauh diatas rata-rata keseluruhan sektor. Hal ini menunjukkan bahwa perusahaan jasa keuangan pada dasarnya tidak selalu dapat memanfaatkan keuntungan karena skalanya yang lebih besar, terutama antara skala usaha kecil dan skala usaha menengah. Gambaran ini akan lebih lengkap lagi jika kita kaitkan dengan produktivitas tenaga kerja yang mengindikasikan kemampuan untuk mendukung jaminan hidup yang layak bagi pihak yang terlibat dalam kegiatan dimaksud. Pertanyaan penting selanjutnya adalah mengapa jasa keuangan, persewaan dan jasa perusahaan sangat produktif dan sangat kompetitif. Diantara jawaban atas pertanyaan tersebut adalah bahwa ; usaha disektor ini harus memenuhi persyaratan legal $(\mathrm{BH}, \mathrm{ijin}$, persyaratanteknis); dikelola oleh kelompok profesional; interaksi dengan dunia bisnis yang luas; kandungan IPTEK yang tinggi; terbiasa dengan hubungan kontraktual yang lugas; relatif lebih transparan dibanding kelompok lain; dan adanya pengawasan yang kuat baik oleh pengawasan Pemerintah maupun pengguna jasa. Dilihat dari produktivitas tenaga kerja secara keseluruhan untuk usaha kecil dan menengah mengalami keadaan yang terus merosot walaupun hanya dalam derajad yang tipis.

Persoalan lain dalam hal produktivitas tenaga kerja adalah ketimpangan yang sangat menyolok antara usaha kecil dengan usaha besar yang digambarkan satu berbanding duaratus. Sektor yang mencerminkan adanya kesetaraan dalam produktivitas tenaga kerja hanyalah sektor keuangan, persewaan dan jasa perusahaan. Kinerja usaha kecil dan usaha menengah pada sektor ini telah sama dan menggambarkan perkembangan yang telah mulai keluar dari krisis. Patut dicatat bahwa dengan adanya sektor keuangan, persewaan dan jasa keuangan skala kecil dan menengah yang produktif dari segi perusahaan dan tenaga kerja akan menjadi sektor pendukung yang efisien bagi tumbuhnya UKM.

\section{Arah dan Strategi Pengembangan LKM}

Permasalahan yang dihadapi oleh LKM terutama LKM bukan bank pada dasarnya dapat digolongkan ke dalam hal-hal yang bersifat internal dan eksternal. Yang bersifat internal meliputi keterbatasan sumberdaya manusia, manajemen yang belum efektif sehingga kurang efisien serta keterbatasan modal. Sementara faktor yang bersifat eksternal meliputi kemampuan monitoring yang belum efektif, pengalaman yang lemah serta infrastruktur yang kurang mendukung. Kondisi inilah yang mengakibatkan jangkauan pelayanan LKM terhadap usaha mikro masih belum mampu menjangkau secara luas, sehingga pengembangan LKM yang luas akan sangat penting perannya dalam membantu investasi bagi usaha mikro dan kecil. Upaya yang dapat dilakukan untuk memperkuat LKM dapat dilakukan melalui : a) Perkuatan permodalan dan manajemen lembaga keuangan masyarakat (KSP/USP dan LKM) b) Penggalangan 
dukungan dan fasilitasi pembiayaan UKMK dengan lembaga keuangan c) Penggalangan partisipasi berbagai pihak dalam pembiayaan UKMK (Pemda, Laur Negeri, dll) d) Optimalisasi pendayagunaan potensi pembiayaan UKMK di daerah (Bagian Laba BUMN, Dana Bergulir, Yayasan, Bantuan Luar Negeri) e) Peningkatan Capacity Building LKM f) Training bagi pengelola LKM, untuk meningkatkan kapasitas pengelola LKM g) Perlu adanya lembaga penjamin untuk menjamin kredit LKM dan tabungan nasabah LKM dan BDS yang mampu memberikan fasilitasi manajemen, keuangan, dll.

Pengendalian dan pembinaan /fasilitasi, serta pengembangan kelembagaan (organisasi dan manajemen), meningkatkan kompetensi dan profesionalisme pengelola KSP/USP-LKM melalui diklat terus menerus sangat diperlukan. Pengembangan kemampuan layanan bagi anggota, meningkatkan jumlah produk keuangan yang didukung dengan pengembangan jejaring. Pengembangan jejaring antara lain meliputi jejaring : a) Antar $\mathrm{KSP} / \mathrm{LKM}$, mendayagunakan lembaga simpan pinjam sekunder yang berperan mengatur interlending diantara KSP/USP Koperasi dan LKM b) Antara KSP/USP dan LKM dengan lembaga keuangan lain, meningkatkan akses untuk dana pinjaman maupun equity.

Dalam memperkuat USP/KSP ke depan paling tidak ada tiga langka yang harus dilakukan : Pertama, harus dilakukan pemisahan koperasi simpan pinjam dan tidak boleh dicampur/dilaksanakan sebagai bagian dari koperasi serba usaha, terutama bila USP sudah menjadi besar dan sangat dominan; Kedua, harus segera diorganisir kedalam kelompokkelompok KSP sejenis untuk melaksanakan integrasi secara utuh, sehingga peminjaman dan penyaluran dana antar KSP dapat terjadi dan berjalan efektif; Ketiga, perlu dikembangkan sistem asuransi tabungan anggota, asuransi resiko kredit serta lembaga keuangan pendukung lainnya. Disamping itu mekanisme pengawasan yang baik dan efektif akan menjamin bekerjanya mekanisme mobilisasi dana dan pemanfaatannya secara efektif. Pengalaman keberhasilan Bank Bukopin yang mengembangkan supervisi dan sistem online pada pola Swamitra juga telah membuktikan, bahwa integrasi KSP dengan Lembaga Keuangan Modern/berpengalaman dalam hal ini bank akan memperkuat kedudukan koperasi. Model ini harus menjadi pelengkap cara memajukan KSP ditanah air. Berbagai dukungan perkuatan seperti perkuatan permodalan : P2KER (Proyek Pengembangan Kemandirian Ekonomi Rakyat), PUK (Pengembangan Usaha Kecil), Dana Penghematan Subsidi BBM, MAP (Modal Awal dan Padanan) akan terus diupayakan, pengendalian (monitoring, evaluasi, pengawasan, penilaian kesehatan) LKM juga akan terus dikembangkan, pengembangan pola dan lembaga penjaminan lokal serta pengembangan biro kredit, informasi kinerja UMK di masa lalu (track record). Arah Lembaga Keuangan Mikro ke Depan : a) Mengatasi status legal agar jelas, diarahkan menjadi Bank, Koperasi atau LKM yang saat ini sedang disiapkan RUU LKM; b) Pengawasan lebih intensif untuk melindungi pihak ketiga (penabung); c) Pengembangan jaringan melalui penumbuhan lembaga keuangan sekunder, jaringan on line untuk peningkatan mutu pelayanan kepada masyarakat lokal.

Dengan demikian pelayanan yang luas serta menjangkau lapisan usaha mikro yang luas akan membawa pasar keuangan lebih bersaing, sehingga ketergantungan usaha mikro terhadap pelepas uang dapat ditekan atau ditiadakan. Pola pengembangan LKM juga harus memberikan pilihan yang luas bagi masyarakat nasabah apakah melalui pola konvensional atau pola bagi hasil (pola syariah). Baitul Mal Wa Tamwil (BMT) sebagai model tertua LKM syariah saat ini telah memiliki 3.000 unit dibawah pembinaan Pusat Inkubasi Bisnis Usaha Kecil (PINBUK), serta model Baitul Tamwil Muhamadiyah (BTM), Koperasi Pondok Pesantren, Koperasi Syirqoh Mu'awanah dan Lembaga Pengelolah Zakat yang mengembangkan program ekonomi produktif bagi penerima zakat ini akan berkembang dan tumbuh lebih banyak LKM karena sudah ada perlindungan hukum tetapi untuk LKM binaan memerlukan perlindungan tersendiri.

\section{METODE PENELITIAN}

Metode penelitian yang digunakan dalam penelitian ini adalah metode Survei. Metode survei adalah penelitian yang mengambil sampel dari suatu populasi dan menggunakan kuesioner sebagai alat pengumpulan data yang pokok. Jenis penelitian ini adalah penelitian kausalitas yaitu 
penelitian yang ingin mencari penjelasan dalam bentuk hubungan sebab akibat (causeeffect) antar beberapa konsep atau beberapa variable independent yakni meliputi Suku Bunga Pembiayaan Usaha Mikro Dan UKM dan Produktivitas Usaha dan Tenaga Kerja, serta variable dependent yaitu Pertumbuhan Ekonomi.

\section{Teknik Sampling}

Teknik sampling (teknik pengambilan sampel) berdasarkan simple random sampling karena pengambilan sample anggota populasi dilakukan secara acak tanpa memperhatikan strata yang ada dalam populasi itu.

Data yang diperlukan untuk menunjang penelitian ini adalah data sekunder yang dikumpulkan dari Laporan Bank BI tentang Penyaluran Kredit Usaha Mikro dan UKM serta Laporan APBN 2017.

\section{Teknik Analisis Data}

Dalam penelitian ini analisis data menggunakan pendekatan Regresi Data Panel menggunakan Software Eviews. Tujuan penggunaan sofware Evies adalah membantu peneliti untuk tujuan prediksi. Model formalnya mendefinisikan variabel laten adalah linear agregat dari indikatorindikatornya. Weight estimate untuk menciptakan komponen skor variabel laten didapat berdasarkan bagaimana inner model (model struktural yang menghubungkan antar variabel laten) dan outer model (model pengukuran yaitu hubungan antara indikator dengan konstruknya) dispesifikasi. Hasilnya adalah residual variance dari variabel dependen.

\section{HASIL PENELITIAN DAN PEMBAHASAN}

Pembiayaan bagi usaha mikro dan UKM adalah penting tetapi bukan segalanya. Itulah ungkpaan yang selalu dinasehatkan oleh para ahli yang meneliti pembiayaan bagi para pengusaha. Sebaiknya setiap kali kita melakukan interview kepada pengusaha terutama pengusaha kecil jawabnya pasti kekurangan modal, sehingga usahanya tidak maju. Gambaran menjadi lain pula ketika membaca berita di media masa bahwa dana sedang berada di perbankan sangat besar dan penyediaan kredit bagi pengembangan usaha tersedia. Jika dari biasanya yang sebenarnya terjadi, untuk memahami persoalan ini kita perlu melihat pembiayaan usaha bagi para pengusaha.

Hasil penelitian disajikan pada tabel di bawah ini:

Tabel 1. Hubungan Suku Bunga Pembiayaan Usaha Mikro Dan UKM serta Produktivitas Usaha dan Tenaga Kerja terhadap Tingkat Pertumbuhan Ekonomi

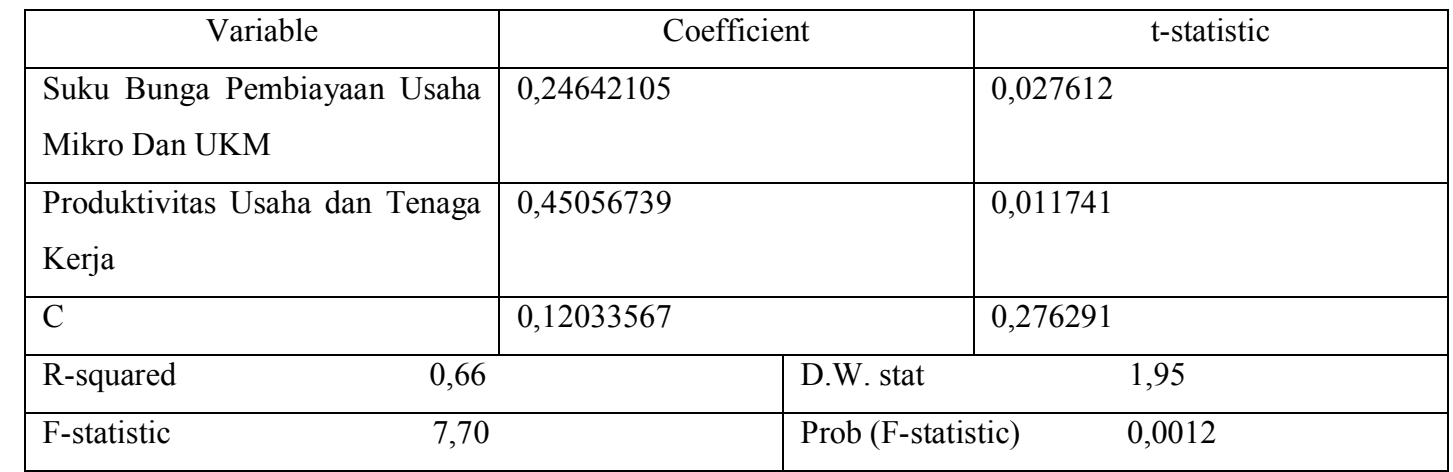

Variabel independent :

1. Suku Bunga Pembiayaan Usaha Mikro Dan UKM

2. Produktivitas Usaha dan Tenaga Kerja

Hasil penelitian menunjukkan bahwa Suku Bunga Pembiayaan Usaha Mikro Dan UKM berpengaruh signifikan terhadap terhadap Tingkat Pertumbuhan Ekonomi dengan nilai t-statistic sebesar $0,027612(<$ $0,05)$ sedangkan Produktivitas Usaha dan
Tenaga Kerja juga berpengaruh signifikan terhadap Tingkat Pertumbuhan Ekonomi dengan nilai t-statistic sebesar 0,011741 (< $0,05)$.

Pada dasarnya pemberdayaan usaha oleh pelaku ekonomi lapis bawah memang 
bertumpuh pada kemandirian dan kekerabatan, kemudian pada tahap berikutnya secara kelembagaan yang masih bersifat lokal dan imformal. Namun di masa lalu juga terdapat lembaga formal pada tingkat desa yang merupakan bagian penting dari pemberdayaan bagi ekonomi lapis bawah di pedesaan yang melekat pada pemerintahan di desa. Kemudian pada tahap berikutnya masuklah pasar keuanganpedesaan melalui koperasi, program pemerintah dan perbankan. Mengutip laporan BPS, 35,10\% UKM menyatakan kesulitan permodalan, kemudian diikuti oleh kepastian pasar $25,9 \%$ dan kesulitan bahan baku $15,4 \%$. Jika kita ikuti jawaban tersebut sebenarnya kesulitan permodalan adalah resultante dari kesulitan mendapatkan kepastian pasar karena ketidakmampuan menjamin kepastian produksi.

Oleh karena itu pemecahan masalah pembiayaan UKM tidak sebatas masalah kekurangan modal, sehingga diperlukan pemecahan yang komprehensif. Hal yang mungkin agak kurang dipahami adalah praktek terbaik dimanapun pembiayaan usaha, terutama pemula, selalu didahului dengan sumber modal sendiri atau modal keluarga atau jika tidak bersumber dari angle Capital yang dasarnya adalah kepercayaan dan kegigihan si pelaku. Dalam hal demikian sebenarnya yang harus juga menjadi perhatian kita adalah usaha yang menyediaakan jasa untuk memecahkan pembiayaan usaha kecil hingga sampai pada perbankan. Pembiayaan bagi UKM di negara berkembang pada umumnya masih diharapakan dari perbankan. Di sisi lain perubahan paradigma pemberian dukungan pembiayaan UKM dari kredit program kepada mekanisme pasar jasa keuangan akibat perubahan UU 23/1999 tentang Bank Indonesia dan berbagai rencana program pemulihan ekonomi yang tercantum dalam nota kesepakatan dengan IMF telah memberikan pelajaran baru. Sejak akhir 2016 semua kredit program dihentikan, sehingga Pemerintah mengubah dukungannya dari memberikan subsidi dan penjaminan pada kredit program sektoral perbankan (seperti BIMAS, KKPA dll.) menjadi dukungan perkuatan LKM terutama KSP/USP sejak tahun 2017 sebagai mekanisme fiskal biasa. Hal ini diharapkan relatif tidak menimbulkan distorsi pasar keuangan mikro kecuali hanya memperkuat para pelaku untuk semakin kompetitif dan memperluas jangkauan
Meskipun stimulan fiskal untuk LKM ini baru menjangkau sekitar 15-20 persen LKM, namun telah mendorong tumbuh kembangnya kekuatan kredit mikro non bank.

dalam $\begin{array}{ccr}\text { Sebagai pelaku mereka } & \text { termasuk } \\ \text { sektor } & \text { keuangan. } & \text { Apabila }\end{array}$ perkembangan ini menjadi instrumen perkuatan yang efisien, maka instrumen fiskal untuk perkuatan LKM akan terbukti lebih efektif disertai dengan tingkat distorsi yang rendah sehingga dapat menjadi pilihan baru bentuk intervensi yang ramah pasar. Secara garis besar, kebijakan perbankan terdiri dari: (1) program penyehatan perbankan, meliputi penjaminan pemerintah bagi bank umum dan BPR, rekapitalisasi bank umum dan restrukturisasi kredit perbankan; (2) pemantapan ketahanan sistem perbankan yang meliputi pengembangan infrastruktur perbankan, peningkatan good corporate governance dan penyempurnaan pengaturan dan pemantapan sistem pengawasan bank; (3) upaya pengembangan UMKM dalam rangka pemulihan fungsi intermediasi perbankan.

Berdasarkan Laporan Perekonomian Bank Indonesia tahun 2017, peran Bank Indonesia dalam pengembangan UMKM dilakukan dengan tiga pendekatan, yaitu: (1) kebijakan kredit perbankan; (2) pengembangan kelembagaan; dan (3) pemberian bantuan teknis. Keterbatasan UMKM dalam memperoleh pelayanan kepada sektor perbankan merupakan salah satu kendala belum optimalnya fungsi intermediasi perbankan. Menyikapai hal tersebut, selama tahun 2017, upaya yang ditempuh Bank Indonesia dalam pengembangan UMKM lebih ditekankan pada upaya peningkatan akses UMKM kepada sektor perbankan. Melalui pendekatan kebijakan kredit, upaya yang dilakukan Bank Indonesia antara lain dengan senantiasa mendorong bank umum dan BPR untuk meningkatkan penyaluran kredit UMKM sesuai dengan rencana bisnis masingmasing bank dengan tetap memperhatikan prinsip kehati-hatian.

Dalam rencana bisnis 2018, 14 bank umum (sekarang 13 bank) yang menguasai $80 \%$ aset perbankan nasional (systemically important banks) dan BPR, menetapkan rencana penyaluran kredit kepada sektor UMKM sebesar Rp. 30,9 triliun. Dalam realisasinya dicapai jumlah Rp. 35,9 triliun, atau $116 \%$ dari target. Namun pada tahun 2003, kredit 50 baru yang disalurkan 
perbankan ke sektor UMKM sebesar Rp. 26,9 triliun atau $63,82 \%$ dari total rencana perbankan untuk penyaluran kredit UMKM sebesar Rp. 42,3 triliun. Selain mendorong perbankan menyalurkan kredit pada UMKM, Bank Indonesia juga mendukung pembiayaan UMKM melalui penyediaan KLBI relending dalam rangka kredit program oleh BUMN Koordinator pengelola. Hal ini merupakan tindak lanjut pasal 74 UU No. 23/1999, yang mengamanatkan pengalihan pengelolaan KLBI dalam rangka kredit program kepada tiga BUMN Koordinator yang ditunjuk pemerintah, yakni BRI, BTN, dan PT. Permodalan Madani (PNM). Tiga BUMN Koordinator tersebut berwenang menyalurkan kembali (relending) angsuran KLBI yang diterima oleh bank pelaksana sampai dengan KLBI dimaksud jatuh tempo. Jumlah angsuran KLBI yang disalurkan kembali mencapai $\mathrm{Rp}$. 2,3 triliun atau mencapai $56 \%$. Selain itu, dalam membantu penyediaan dana untuk kredit program, Bank Indonesia melakukan pembelian Surat Utang Pemerintah (SUP) No. 005 dalam rangka kredit program dengan plafon Rp. 9,9 triliun pada akhir Desember 2018. Sampai dengan akhir Juli 2018, dana yang tersedia adalah Rp. 3,1 triliun, dan telah ditarik oleh pemerintah sebesar Rp. 850 milyar, sehingga dana yang masih ditarik sebesar Rp. 2,2 triliun. SUP dimaksud berjangka waktu 10 tahun yang akan berakhir pada 10 Desember 2018 dan dikenakan suku bunga SBI 3 bulan. Pada pendekatan kelembagaan, salah satu upaya BI dalam mencari solusi bagi peningkatan fungsi intermediasi perbankan dan pemulihan sektor riil dilakukan dengan menyelenggarakan Forum Dialogis Kawasan Barat Indonesia (FD-KBI).

\section{PENUTUP}

1. Hasil penelitian menunjukkan bahwa Suku Bunga Pembiayaan Usaha Mikro Dan UKM berpengaruh signifikan terhadap terhadap Tingkat Pertumbuhan Ekonomi dengan nilai t-statistic sebesar 0,027612 (< $0,05)$ sedangkan Produktivitas Usaha dan Tenaga Kerja juga berpengaruh signifikan terhadap Tingkat Pertumbuhan Ekonomi dengan nilai t-statistic sebesar 0,011741 (< $0,05)$.

2. Ada tiga faktor penting untuk memperbaiki pertumbuhan perekonomian nasional yang kesemuanya berada kekuatan internal perusahaan dan berhubungan dengan produktivitas karena pada dasarnya perbaikan daya saing salah satu kuncinya adalah penurunan ongkos. Ketiga faktor dimaksud adalah: (i) adanya inovasi dan perbaikan teknologi yang terus menerus menuju penurunan biaya;(ii)pengembangan pemanfaatan teknologi komunikasi dan informasi untuk meningkatkan produktivitas dan penghematan waktu; dan;(iii)Pemanfaatan jaringan kerjasama untuk pengembangan pasar secara meluas.

3. Untuk penciptaan basis UKM yang kokoh pendekatan pengembangan Klaster Bisnis/Industri perlu ditumbuh kembangkan. Kehadiran klaster yang senergik dari kegiatan hulu ke hilir, atau antara kegiatan inti (pokok) dengan kegiatan pendukung, penyediaan bahan baku dan outlet pemasaran akan mempercepat dinamika usaha di dalam klaster tersebut, termasuk interaksi dengan usaha besar yang ada di kawasan tersebut atau terkait. Pendekatan klaster ini pada dasarnya untuk mengefektifkan pola pengembangan dengan menjadikannya sebagai titik pertumbuhan bagi bisnis UKM. Inti dari strategi penciptaan klaster yang terpadu dan kokoh adalah membangun suatu sinergi untuk mencapai suatu "broad base economic growth" atau pertumbuhan ekonomi dengan basis yang luas.

4. Persfektif kebutuhan wirausahawan baru yang mendesak selain dilihat dari kenyataan rendahnya pendirian perusahaan baru dibandingkan dengan besarnya ekonomi dan jumlah penduduk, juga didasari atas kenyataan bahwa lebih 97\% unit usaha yang ada adalah usaha skala mikro. Ini berarti usaha yang ada di Indonesia dikelola oleh pengusaha dengan kemampuan pengelolaan yang rendah. Sehingga persoalan kebutuhan wirausaha bagi Indonesia mempunyai sasaran yakni mengisi kebutuhan perluasan perusahaan yang ada dan kebutuhan untuk mengembangkan wirausaha baru untuk membuat ekonomi Indonesia lebih kompetitif.

5. Pada dasarnya pemberdayaan usaha oleh pelaku ekonomi lapis bawah memang bertumpuh pada kemandirian dan kekerabatan, kemudian pada tahap 
berikutnya secara kelembagaan yang masih bersifat lokal dan imformal. Namun adanya Lembaga Keuangan yang baik dapat mengakibatkan UKM dan perekonomian berkembang.

\section{DAFTAR RUJUKAN}

Adiningsih, Sri, 2003. The Indonesia Business Rop in AFTA, Indonesia Business Perspective, Volume V, No. 3, PT. Harvest International Indonesia, March

Bhalla, A. S. (2017), Can high technology help Third World take-off? Economic and Political Weekly, Volume 22, No. 27, pp. 1082-1086.

Cravo, T. A. (2016), SMEs and economic growth in the Brazilian micro-regions. Papers in Regional Science, Volume 89, No. 4, pp. 711-734. http://dx.doi.org/10.1111/j.14355957.2010.00301.x

Fagerberg, J., M. Srholec and B. Verspagen (2011), Innovation and Economic Development. Handbook of the Economics of Innovation, North Holland. Freel, M. S. (2000), Do small innovating firms outperform noninnovators? Small Business Economics, Volume 14(3), pp. 195210.

http://dx.doi.org/10.1023/A:10081002 06266

Gault, F. (2010), Innovation Strategies for a Global Economy. International Development Research Council (IDRC), Canada. Government of Pakistan (1990 to 2013), Pakistan Economic Survey. Islamabad: Ministry of Finance, Government of Pakistan.

Government of Pakistan (2009), Statistical Yearbook. Islamabad: Federal Bureau of Statistics, Government of Pakistan. Government of Pakistan, Fifty Years of Pakistan in Statistics (1947-97), Volume $(1,2,3)$. Islamabad: Federal Bureau of Statistics.

Hall, B. H., F. Lotti and J. Mairesse (2009), Innovation and productivity in SMEs: Empirical evidence for Italy. Small Business Economics, Volume 33(1), pp.

13-33. http://dx.doi.org/10.1007/s11187-0099184-8

Jeppesen, S. (2015), Enhancing competitiveness and securing equitable development: Can small, micro, and medium-sized enterprises (SMEs) do the trick? Development in Practice, Volume 15 (3\&4), pp. 463474.

http://dx.doi.org/10.1080/0961452050 $\underline{0076100}$

Khan, Iqbal M. (2014), Unlocking the Potential of Small Enterprises for Economic Development, Innovative Development Strategies. SURE Business Directories \& Guide Publisher, Lahore, Pakistan. SUBHAN et al.: Innovation and Economic Development 173

Kharbanda, V. P. (2011), Facilitating innovation in Indian small and medium enterprises: The role of clusters. Current Science, Volume 80(3), pp. 343-348

Lefebvre, E. and L. A. Lefebvre (2001), Innovative capabilities as determinants of export performance and behavior: a longitudinal study of manufacturing SMEs. In A. Kleinknecht and P. Mohnen (eds.), Innovation and Firm Performance: Econometric Explorations of Survey Data. London: MacMillan and Basingstoke: Palgrave.

Motohashi, K. (2011), Use of plant level micro-data for SME innovation policy evaluation in Japan. Ministry of Economy, Trade and Industry (METI), Japan and Research Institute of Economy Trade and Industry (RIETI), Japan, RIETI Discussion Paper Series 01-E-006.

Ohashi, H. (2017), How to measure the outcome of innovation: Application to product innovation? Conference Paper; Towards Global Innovation Ecosystem beyond National Innovation. Piëst, B. (1994), Planning comprehensiveness and strategy in SME's. Small Business Economics, Volume 6(5), pp. 387-395. http://dx.doi.org/10.1007/BF01065142

SBP (1990 to 2013), State Bank Reports. Karachi: State Bank of Pakistan. Seguino, S. (2000), The effects of 
structural change and economic liberalization on gender wage differential in South Korea and Taiwan. Cambridge Journal of Economics, Volume 24(4), pp. 437459.

http://dx.doi.org/10.1093/cje/24.4.437

Soriano, D. R. and S. R. Dobon (2011), Linking globalization of entrepreneurship in small organizations. Small Business Economics, Volume 32(3), pp. 233239. http://dx.doi.org/10.1007/s11187$\underline{008-9155-5}$ 